University of Nebraska - Lincoln

DigitalCommons@University of Nebraska - Lincoln

Agronomy \& Horticulture -- Faculty Publications

Agronomy and Horticulture Department

$9-1961$

\title{
The Living Network in Prairie Soils
}

J. E. Weaver

University of Nebraska-Lincoln

Follow this and additional works at: https://digitalcommons.unl.edu/agronomyfacpub

Part of the Plant Sciences Commons

Weaver, J. E., "The Living Network in Prairie Soils" (1961). Agronomy \& Horticulture -- Faculty Publications. 442.

https://digitalcommons.unl.edu/agronomyfacpub/442

This Article is brought to you for free and open access by the Agronomy and Horticulture Department at DigitalCommons@University of Nebraska - Lincoln. It has been accepted for inclusion in Agronomy \& Horticulture -Faculty Publications by an authorized administrator of DigitalCommons@University of Nebraska - Lincoln. 


\section{THE LIVING NETWORK IN PRAIRIE SOILS}

\section{J. E. WEAVER}

\section{Introduction}

This study treats of our midcontinental soils and of the wonderful network of roots within them of a vegetation which has clothed them for untold centuries. This vegetation has almost vanished so great has been the toll of the tractor-drawn plow, overgrazing and trampling, injudicious use of poisonous sprays, building of highways, and other causes. Virgin prairie and undisturbed soil occur in quantity only in areas where limestone underlies a shallow soil and prevents plowing or in sand so unstable that destroying the vegetation with its binding roots is almost synonymous with losing the soil. The many thousands of acres of Flint Hills in east-central Kansas and the 18,000 square miles of Sand Hills in Nebraska are examples.

Many years of investigation have permitted thorough examination of grasslands above, in, and below the soil. Several reports have emphasized the individual root habits of grasses, grasslike plants, and forbs. This study is concerned especially with the intimate structure of the continuous network of roots of the several species which dominated and characterized the prairie over an area of thousands of square miles in the central Midwest. This root network is a permanent feature in prairie soils. Years of study have revealed that samples taken in spring, summer, or autumn are the same. The roots of the dominant grasses are long-lived; death and decay of individual roots proceed slowly as does also their replacement by new ones. Many clumps of sod or bunches of grass persist below ground for 15 years certainly and probably for 25 .

\section{Methods}

Studies were made during 1959-1960 at selected typical sites where the soils were fully examined. Roots from the solum, which is often $2 \frac{1}{2}$ feet deep, are presented separately from portions in the underlying parent materials. This has the advantage of giving a more intimate and detailed view of a large sample. The monolith method (19) was used in securing samples of the network formed by roots of grasses. In gently separating the soil from the roots, after long soaking in water, no vertical or lateral displacement of the root network occurred, except that those in the 3-inch width of the monolith settled down to less than 1 inch in thickness. Studies below the solum were made by direct examination in trench walls and by securing monoliths from the deeper soils and parent materials. The writer is under great obligation to John A. Elder, Soil Scientist, of the Conservation and Survey Division, University of Nebraska, Lincoln, for much information about the soils and especially the individual soil profiles.

\section{Observations and discussion} SoILS

GRASSLAND SOILs.--Soil is the unconsolidated outer layer of the earth's crust which, through the processes of weathering and the incorporation of organic matter, becomes adapted to the growth of plants. It is usually underlaid by unconsolidated parent materials into which the deeper roots of plants frequently extend. The soil often contains and acts upon a much more extensive portion of the plant body than does the atmosphere. This is especially true of grassland soils. The true soil or solum is usually made of the parent materials which it covers. Indeed, parent materials constitute the bulk of the soil and for a long time determine its physical character. As the soil slowly matures throughout the centuries, however, its mineral composition departs more and more from that of the parent material.

Brunizems are grassland soils developed under a relatively high precipitation, 25 inches or more. They are found on somewhat poorly drained to well drained sites under tall and mid grasses, chiefly blue stems. They have been leached to the extent that they do not have a horizon of calcium carbonate as do the Chernozems, but they do have a high degree of base saturation. They are rich in organic matter, especially in the upper portion, and are well supplied with nutrients necessary for a luxuriant growth of grasses and forbs. The surface soils over most of the area are slightly acid. Their high fertility and the favorable climate where they occur make them among the most productive in the world for grain and grass crops.

The profile of Brunizems consists of a dark grayish brown A horizon 8-16 inches thick, a grayish brown to brown or yellowish brown B horizon 12-24 inches thick, and a light yellowish brown to pale brown $\mathrm{C}$ horizon of parent materials (fig. 1). Principal textures are loam and silty clay loam in the A horizon, clay loam or silty clay loam in the B horizon, and loam or silt loam in the $\mathrm{C}$ horizon. The $\mathrm{B}$ horizon is finer textured than either the $\mathrm{A}$ or $\mathrm{C}$. The greater abundance 
of silt and clay has a marked effect upon the ease or difficulty of removal of plant roots from the soil. In the B horizon the soil is distinctly blocky and often is separated from the roots with great difficulty. Here root penetration is much more difficult and branching is usually less pronounced. Many rootlets are found appressed to the surface of the soil aggregates between which water penetrates more readily, air is more abundant, and nutrients apparently are more concentrated. Relatively few roots penetrate to the interior of the aggregates. In the massive structure of the $\mathrm{C}_{1}$ horizon, which is defined as the upper foot or two of the loose and decayed mineral material beneath the solum (A and B horizons), roots are removed much more easily. Many grass roots occur here, and roots of forbs extend many feet into the parent material. A pale brown or light yellow color usually characterizes the massive layer $\left(C_{1}\right.$ horizon and deeper parent material) which occurs at a depth of $2 \frac{1}{2}-4$ or more feet. Here the carbonate content is high; streaks and pockets of chalky material are usually numerous. Despite great variation in texture and structure of the parent materials, the deeper roots of grasses and forbs are comparatively easily separated from them either by pick or by washing. Both the solum and parent materials readily absorb water and are almost constantly moist to great depths under a precipitation of 25-32 inches. Exceptions occur, of course, during periods of drought which extend over several years (18).

Drier regions have soils with a calcium carbonate horizon; Chernozem soils are found in the most humid parts. They develop under a continental climate usually with an excess of evaporation, as measured from a free water surface, over precipitation. The luxuriant prairie grasses have exerted a powerful soilbuilding influence. Much humus is derived from roots of plants which decay where they grow throughout the soil profile. The deep distribution of humus is also in part the result of the action of earthworms, insects, etc., and the extensive burrowing of rodents, often to many feet in depth.

One learns much about soil structure and texture by separating roots from it in the walls of a trench or by slowly washing the soil from the roots in inclosed samples taken from the field. Both Brunizem and Chernozem soils are fine in texture, being mostly composed of silt and clay; they are sufficiently supplied with calcium to be neutral or only slightly acid. In the granular soil of the A horizon roots penetrate easily and spread widely, thoroughly ramifying throughout the soil. This horizon has the greatest supply of roots. They are easily separated from the soil, since much of its colloidal clay has been lost to the B horizon. The forces of weathering, especially freezing and thawing and alternate wetting and dry- ing, together with high humus content and the favorable effects of root activities, have combined to produce this excellent granular structure. In the B horizon the clay content is higher, much of the lime has been leached away, except in the lower portion of Chernozem soils, and upon drying the soil may shrink and cleave into long perpendicular prisms.

Below the solum lie the parent materials. These are rocks such as limestone, sandstone, granite, etc.

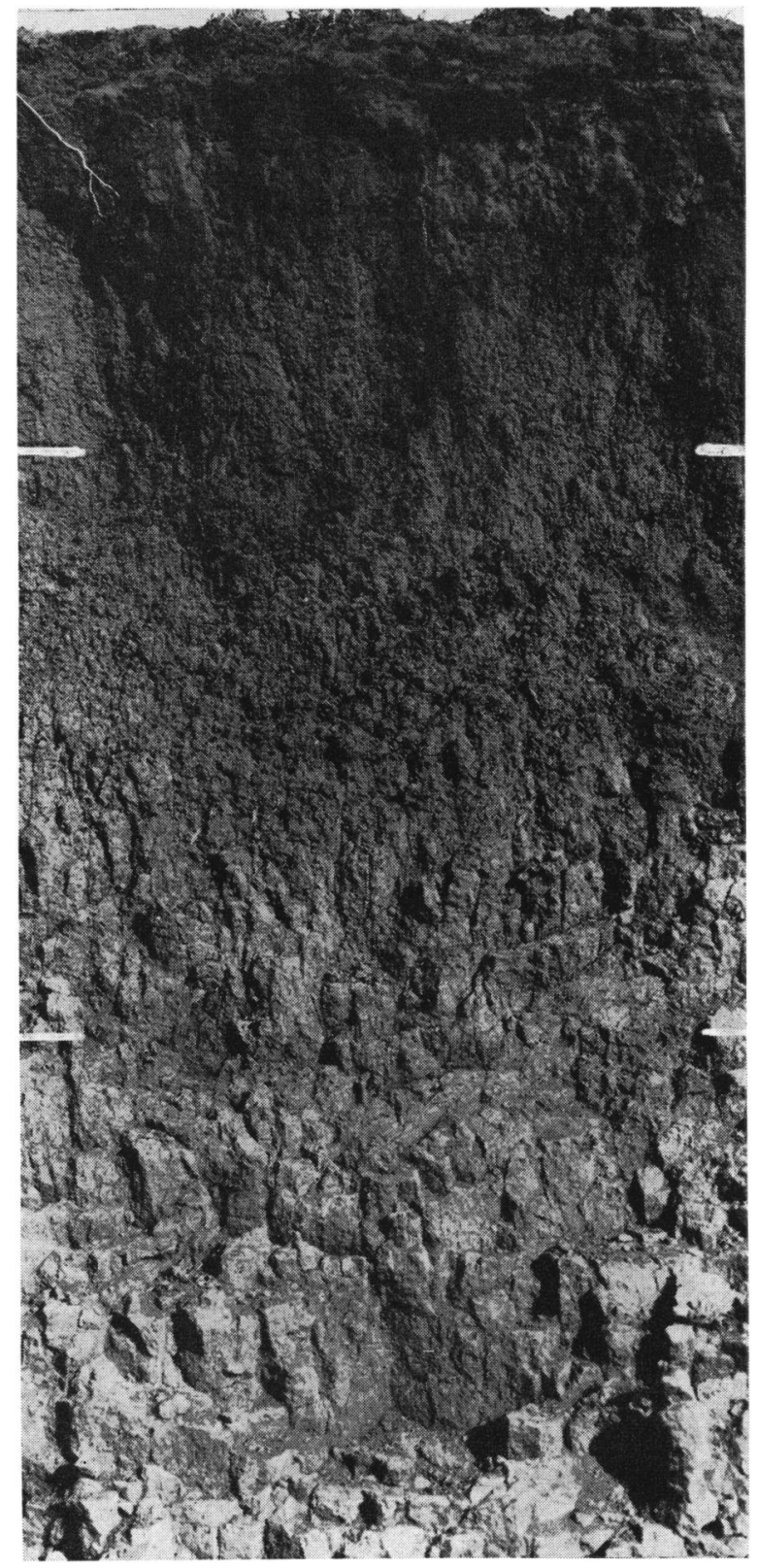

Fig. 1.-Five-foot profile of a deep Brunizem soil near Lincoln, Nebraska. Dark-colored A horizon is 16 inches deep, and subsoil or B horizon extends downward to 39 inches where it gives way to parent materials. Photo furnished by $\mathrm{H}$. A. WOLFANGER. 
or loose incoherent masses such as beds of sand, gravel, clay, or volcanic ash (11). In the portion of the prairie concerned in this study they are primarily deposits of wind-blown loess and glacial drift. The loess has a mineralogical composition of quartz, feldspars, lime, etc.; it is silty in texture and unconsolidated in structure. In places the loess is $\mathbf{5 0}$ or more feet in depth; in others it has been removed from underlying glacial deposits or has become intimately intermixed with them. The glacial drift is composed of clay minerals, quartz, feldspar, and lime; it is unconsolidated in structure and moderately fine in texture.

SOIL-FORMING PROCESSES.-Physical weathering (disintegration or fragmentation) as a result of freezing and thawing, wind and water erosion, and root action is accompanied by chemical corrosion or decomposition. The latter includes the processes of hydrolysis, hydration, carbonation, oxidation, and solution. It is by these processes that the parent materials are molded into the framework or skeleton of the soil. Quite in contrast to these destructive physical and chemical activities are constructive processes which convert the modified parent materials into soil.

The introduction of living matter, which accompanies or follows the accumulation of parent materials, introduces the biological force which is largely responsible for constructional processes of soil development. Residues of plants and animals return more to the soil than green plants take away. This added organic matter produces the fundamental change which is largely responsible for soil development: the soil now contains stored-up energy and becomes the abode of bacteria, protozoa, etc. Throughout the soil, raw wastes are converted by the activities of micro-organisms into dark colored organic matter of high carbon content. This is one of the most important functions of micro-organisms. Total organic matter usually constitutes $1-5 \%$ of the dry weight of the prairie soil. Energy for the micro-organisms comes from the oxidation of organic residues, changing them into the nitrogenous and mineral compounds needed by green plants for continuous growth. "The major soil forming processes in Brunizems are: (a) the accumulation of organic matter in the surface layer, (b) leaching of bases and development of acidity in the A and B horizons, (c) the formation of a high cation-exchange capacity clay, and (d) the accumulation of this clay in the B horizon" (12). "The soil forming processes leading to the development of Chernozems are mainly: (a) the addition of organic matter to the surface horizons, (b) the formation of clay and development of structure in the subsoil, and the movement of bases by leaching to a zone of accumulation in the lower part of the solum" (5).

Variations in soil properties are associated with the nature of parent materials, topography, climate, organisms (particularly vegetation), and time. More will be said about primary parent materials, especially their texture and structure, and topography in individual soil profile descriptions. In general the topography in the area studied is undulating to rolling but occasionally hilly. The more direct influences of climate on soil formation are associated with temperature and precipitation. Average annual temperature is about $50^{\circ} \mathrm{F}$., the average length of the frostfree period about 160 days, and the average depth of frost penetration 25 inches. The average annual precipitation is $25-32$ inches. The native grass vegetation is associated with soils which are highly fertile because of the good supply of plant nutrient elements in the primary materials, an adequate amount of organic matter, and small amounts of leaching resulting from moderate rainfall. The role of organisms, especially the native vegetation, in soil formation and the considerable abundance and activity below the solum of this vegetation will be considered. As a source of organic matter, roots of plants are of supreme importance since they supply much more tissue than all of the other organisms combined. They not only furnish organic matter for the soil but also bring up plant nutrients from the lower layers to the upper ones. They thus assist in the perpetuation of conditions under which they can grow. Soils near Lincoln are deep to moderate in depth often with sola $2 \frac{1}{2}-3$ feet thick. They have had much time for development and the landscape is moderately stable. While it is not old, it is far from being young.

\section{ROOT NETWORK IN SOLUM IN True Prairie}

DOMINANT GRASSES

Soils in the area where the dominant prairie grasses were studied in 1959-1960 are partly Brunizem and partly Chernozem since the True Prairie extends far beyond the western boundary of Brunizems into the eastern portion of Chernozems. The two chief Brunizem soil associations of the region are the very extensive Sharpsburg-Marshall-Burchard and the Pawnee-Grundy-Butler. The first of these associations occupies a loess-mantled till plain about 250 miles long and 20-60 miles wide in eastern Nebraska and northeastern Kansas just west of the Missouri River. The second occupies a dissected till plain with a discontinuous mantle of loess; it is about 175 miles long and 20-70 miles wide and lies southwest of, but adjacent to, the deeply loess-mantled till plain. Root networks of dominant upland grasses 
will be presented first, followed by those of lowland grasses.

IN soILs OF UPLAND. Sporobolus heterolepis.Rooting habits of Sporobolus heterolepis, prairie dropseed, (and of Andropogon scoparius) were studied in a prairie near Emerald, Nebraska, in Sharpsburg soil. ${ }^{1}$ Sharpsburg soils are well-developed upland soils. The surface silty clay loam has a dark graybrown color and medium acidity. The brown or darkbrown heavy silty clay loam or light silty clay subsoils grade gradually into the loess parent material below about 42 inches. The A horizon where the root samples were taken was 14 inches deep; the B horizon of heavy silty clay loam extended to a depth of about 46 inches. Sharpsburg soils are well drained and have moderately slow permeability in the subsoils. The root zone is deep. Granular soil characterized the A horizon, granules so stable that they are not destroyed by thorough wetting and remain intact for several years after the land is broken and cultivated. Prismatic structure occurred in the upper B horizon, and a blocky structure in the lower part. Here almost perfect cubes of soil about an inch in diameter prevailed. The fine root network was distributed on the faces of the blocks, and only a few roots penetrated into them.

Roots of two bunches of Sporobolus heterolepis, each bunch about 8 inches in diameter, were secured (fig. 2) on a moderately steep $(8 \%)$ slope. Height of foliage of this mid grass is about 15 inches and of flower stalks about 2 feet. The abundant shoots were closely crowded in the bunches. Many roots extended outward from the crown in the upper foot of soil. They crisscrossed in the A horizon and thoroughly occupied the soil between the bunches. This occurred regularly even when bunches $15-20$ years old and $1 \frac{1}{2}$ feet in diameter were widely spaced. Main roots extended downward 4-5 feet. The thousands of branches spread laterally in all directions and, branching again, intertwined to form a very fine-meshed network which occurs not only in this particular site but over many square miles. This species occurs in stands that are nearly pure or are intermixed with small to large amounts of little bluestem and needlegrass (Stipa spartea) with which its roots intermingle and compete for water and nutrients.

Andropogon scoparius. - The sample of Andropogon scoparius, little bluestem, was secured from the same prairie but on a lower northeast slope. The soil profile was very similar to the preceding except that the A horizon was several inches deeper. Height of

${ }^{1}$ Names of grasses are according to Hiтchcock (7). Exact lccations of places where roots were excavated and relief and soil profile descriptions have been filed with the Conservation and Survey Division, University of Nebraska, Lincoln. foliage and flower stalks of this mid grass are about the same as those of prairie dropseed. The root system under the several small bunches of this sod consisted of a network of many main roots and masses of finely branched rootlets, some more than $2 \frac{1}{2}$ feet in length and all well rebranched to the third order (fig. 3). The thorough occupancy of the soil is characteristic of this species, and figure 3 , and the other photographs as well, represents not only the particular sample but also the general root network afforded by these dominant species mile after mile throughout the broad expanse of prairie wherever they occur. Little bluestem is dominant, $\mathbf{- 5 5}-\mathbf{9 0 \%}$ in abundance, in the composition of prairie over more than half of an area of 60,000 square miles in the central Missouri Valley. Its root network is thus the most abundant, most widely distributed, and hence the most characteristic of upland soils.

Similar samples of little bluestem may be secured anywhere in undisturbed upland prairie. The root network was quite as complete between the bunches as under them (23). Deviations occur when other grasses are intermixed or forbs are present.

Stipa spartea.-Needlegrass was excavated from Sharpsburg silty clay loam with a thick solum. This site was on a terrace with a slope of only $1 \%$ about $1 \frac{1}{2}$ miles northwest of Lincoln. The parent material was loess; the soil was well drained, and permeability was moderately slow. The A horizon was 20 inches thick with 6 inches of transition to the B horizon, which reached a depth of 5 feet. This very productive soil was especially favorable to plant growth since the upper $2 \frac{1}{2}$ feet was underlaid with considerable clay which permitted water from spring rains to penetrate only slowly. Needlegrass is a cool-season bunch grass, typical of the drier soils of hill crests and ridges but it sometimes occurs on lower slopes and terraces. Its foliage extends upward $2 \frac{1}{2}-3$ feet and is overtopped in late May and June by conspicuous panicles. The abundant roots spread laterally about $10-12$ inches from the crown and penetrate downward 4-6 feet. In figure 4 the roots are from two well-developed bunches and from several smaller ones between them. Best development of the root network occurred in the A horizon, where it was quite as thick as that of the preceding species. The network of roots was somewhat thinner in the $\mathrm{B}$ horizon, but the intertwining of the thousands of branches shows even more clearly. The soil was well threaded with roots throughout. Communities of needlegrass are common in northern prairies (Minnesota, Iowa, and Nebraska) and in some occupy $10 \%$ or more of the land. In smaller amounts, $1-5 \%$, this grass occurs throughout northern Kansas as well.

While Sharpsburg soils dominate the extensive 

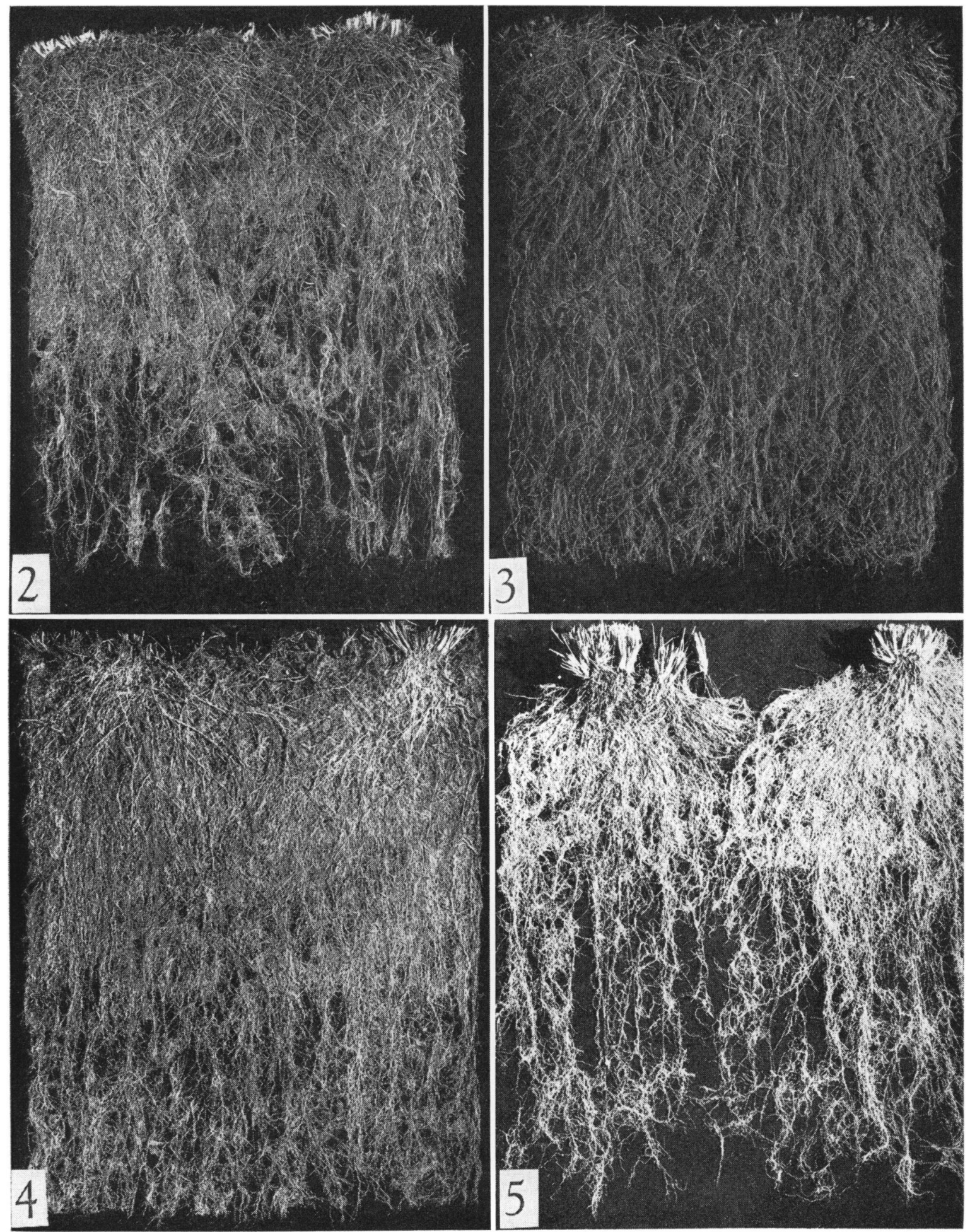

Figs. 2-5.-Root samples 2 feet wide, 3 inches thick, and $2 \frac{1}{2}$ feet deep. Fig. 2, Sporobolus heterolepis (prairie dropseed) showing crisscrossing of roots and excellent fine network of branches. Fig. 3, roct network of Andropogon scoparius (little bluestem) which fully occupies soil. Fig. 4, root network of

Stipa sfartea (needlegrass) which thoroughly occupies A horizon but is somewhat thinner in B. Fig. 5, Stipa spartea from thinner soil in drier site. Cleavage between plants resulted from deep fissure in soil. Network is greatly reduced below 12 inches because of very compact clay. 
loess-mantled area, Pawnee and Burchard soils are developed on slopes and valley sides on outcrops of underlying glacial drift. Conversely, Pawnee and Burchard soils dominate the landscape in the dissected till plain area with small areas of Sharpsburg soils on ridge tops and lower slopes. All are Brunizem soils.

S. spartea was also excavated from Burchard clay loam where the grass grew in a pure stand on an eastfacing, convex slope of about $8 \%, 6$ miles west of Lincoln. This well-drained soil had developed from Kansan till. The A horizon of black silty clay loam, underlaid with very dark brown clay loam, was 12 inches thick. The heavy, dark-colored clay loams of the $\mathrm{B}$ horizon showed no effervescence with hydrochloric acid $(\mathrm{HCl})$ to a depth of 26 inches. The $\mathrm{C}$ horizon occurred at a depth of 30 inches. The soil is well drained, and the subsoil is only moderately permeable. The roots of the vigorous bunches of Stipa showed a remarkable response to a very compact layer of soil. In the upper 12 inches the roots developed normally. At 12-21 inches a heavy clay loam with a subangular blocky structure occurred; from this roots were separated with much difficulty. They were fewer and less branched, except where a fissure occurred in the soil (fig. 5). At 21-30 inches depth in the dark grayish brown clay loam the roots were much better branched and far more easily separated out. At 26-30 inches lime was plentiful in spots and seams, and effervescence with $\mathrm{HCl}$ occurred for the first time; below 30 inches, effervescence was violent. The $\mathrm{pH}$ was 8.5 . Roots, which normally reached depths of 5 feet, were few at $2 \frac{1}{2}-3$ feet and rare below 3 feet in depth.

General.-The root systems of these three upland grasses are similar in size, depth, and degree of branching. Roots of Andropogon scoparius are tan in color, some of those of Sporobolus heterolepis are black, and the younger roots of Stipa spartea are often white. Branches of little bluestem are longest and diverged at various angles; those of needlegrass extend rather horizontally for several feet even at considerable depths; branches of prairie dropseed tend to be shorter and mostly occur at nearly right angles to the main roots.

About twenty-five other grasses are of common occurrence throughout the uplands. A few of these, notably Koeleria cristata (Junegrass) add to the root network only in the solum. Poa pratensis (Kentucky bluegrass), a species found only since the coming of the white man, is moderately deep-rooted. It produces a network which is finer and even more compact than that of most prairie grasses. The roots of the widely scattered Bouteloua curtipendula (sideoats grama) and those of two short grasses, $B$. gracilis and Buchloe dactyloides, which occur more locally and under special conditions, are quite as deep as those of the bluestem but finer and much more branched. The root network of these three xeric grasses, however, is not so well developed in the surface soil of True Prairie, as it is on the Great Plains, where they are important dominants.

This wonderful network extends on and on, both over the hills and across the ravines, for the latter are merely folds in the prairie carpet which mantles vast sections of our land. Where great rivers flow, it may be broken by willows and cottonwoods, oaks and elms, or bordering thickets of shrubs, but in the prairie landscape these are merely incidental features. In the Mixed Prairie of the Great Plains to the westward, streams are bordered by even less woody vegetation, if any, except for a few which have cut deep canyons through the wind-swept plains; even the mighty Missouri and Platte only briefly interrupted the never-ending expanse of root network below the magnificent stands of grass.

In an extensive study of many grasses over wide areas, only once was root depth limited by conditions below the sola. Here the root network was spread even more thickly over the flat surface of impermeable limerock at a depth of 4 feet. In places, however, the network became less dense as a result of layers of claypan, only to become thicker again in a more favorable environment at a greater depth (6). The remarkable network of roots in rocky soil has been revealed by AlBERTSON (1) in an outstanding study among outcrops of limestone in west-central Kansas. Casual observations along road cuts have shown the manner in which the root network is spread non-uniformly but extremely efficiently in the great bluestem prairies commonly known as the Flint Hills, which extend in a belt 30-60 miles wide across east-central Kansas and southward into Oklahoma.

IN SOILS OF LOWLAND.-Three species of lowland grasses, Andropogon gerardi, Spartina pectinata, and Panicum virgatum, were examined on the upper flood plain of Salt Creek 0.6 miles due north of Greenwood, Nebraska. Each of these grasses forms very extensive and almost pure stands on flood-plain soils, big bluestem on those best drained, prairie cordgrass on the most poorly drained, and switchgrass on those of intermediate water content. At Greenwood they were found only a few yards distant, hence a single description of soil will suffice. All are sod formers as a result of their extensive, coarse rhizome development, and roots are distributed uniformly throughout the soil with little or no lateral spread.

Colo soils are the most extensive soils of the flood plains of the central Missouri Valley. They are moderately well drained and occasionally flooded. The surface soils are nearly black silt loam or silty clay loam. The subsoil is a silty clay loam, which is nearly as dark colored as the surface horizons. The permea- 
bility of the subsoil is moderately slow and the root zone is deep. There was no effervescence with $\mathrm{HCl}$ in this soil to a depth of 5 feet.

Andropogon gerardi.-A height of 3 feet is attained by the dense foliage of big bluestem, and the mature flower stalks in late summer reach heights of 6-10 feet. The abundant coarse roots so uniformly distributed throughout the upper soil, and their 2- to 6-inch-long branches formed a splendid network (fig. 6 ). The dense distribution continued for another $1 \frac{1}{2}$ feet, and many roots extended 7 feet deep. Branching throughout was less profuse than that of upland bunch grasses. The network of big bluestem roots is little interrupted anywhere on low, moist ground, since its stands are unusually pure and the rhizomes extend it everywhere.

For purposes of comparison a sample of $A$. gerard $i$ was also excavated from an upland site on Pawnee clay loam about 80 feet from the site where the second sample of Stipa spartea was secured. Pawnee soils are strongly developed upland Brunizems. The surface soils are dark grayish brown to black silty clay loam, loam, or clay loam of medium acidity. The subsoils have a clay texture and contain sand grains and glacial pebbles. They grade abruptly into Kansan-till parent material at a depth of 3-4 feet. They are well-drained soils with slowly permeable and very compact subsoils. The root zone is deep with evidence of restriction of root development in the subsoil horizon. Bunches of big bluestem formed an almost pure stand on this claypan soil on a convex ridgetop of only $3 \%$ slope above the steep hillside where needlegrass was excavated from Burchard soil.

In washing away the soil it was soon apparent that the roots were larger, more abundant, and much more branched in the upper $2 \frac{1}{2}$ feet of soil than is usual (fig. 7). Some ran obliquely more than 12 inches before turning downward. When the dry weight of these roots was compared with the average weight of several samples of big bluestem obtained from a variety of soils, it was $30 \%$ greater. Below $2 \frac{1}{2}$ feet roots were few; nearly all followed the surfaces of the peds in the stiff, compact clay soil. Branches were few and not well developed. This is an example of soil conditions modifying the usual pattern of root development. Roots of big bluestem on other upland sites usually reach depths of at least 5-6 feet. Root distribution of this grass has been studied in fifteen different sites and in ten soil types, but this was the first soil type in which root development was so profoundly modified.

Spartina pectinata.-Prairie cordgrass forms a second tall-grass community. It originally occurred in almost pure stands over hundreds of square miles of low bottom land along the Missouri and other great rivers and their tributaries (17). The coarse foliage often attains a height of 4-7 feet, and mature flower stalks are 6-10 feet high. The surface 6 inches of soil was filled with coarse, woody, extensively branched rhizomes 5-10 mm. thick (fig. 8). The roots are typically fewer but much coarser $(3-5 \mathrm{~mm}$. in diameter) than those of big bluestem. They arise from the rhizomes and the bases of the clumps and penetrate almost vertically downward. Branches, which are neither long nor very abundant, are best developed in the 12-16 inches of surface soil. The root system throughout its entire depth, which is often 8-10 feet, appears quite like that shown below 2 feet. It thus compensates for its poorer network by extending deeply into the parent material.

Panicum virgatum.-Switchgrass has an abundance of branched rhizomes $3-7 \mathrm{~mm}$. thick. It is intermediate between big bluestem and prairie cordgrass in its habitat requirements, in coarseness and height of foliage, as well as in root development (fig. 9). Its main roots are intermediate in size $(2-4 \mathrm{~mm}$. thick); they are somewhat less abundant but usually exceed in depth those of big bluestem. They equal or exceed those of prairie cordgrass in depth and pursue a similar directly downward course. The roots are somewhat better branched than in prairie cordgrass, but branches are often only 2-4 inches long and they are not so thickly distributed as those of big bluestem. Hence the general root network of switchgrass is also intermediate in density. It may well be that the continuously greater supply of water in the wetter habitats of switchgrass, and especially of prairie cordgrass, is an environmental condition reflected in the more open network of rhizomes and fewer roots than characterizes big bluestem.

General.-Two other lowland grasses are of considerable abundance and are more or less intermixed with the preceding dominants. Sorghastrum nutans (Indian grass) has water requirements and habits almost identical with those of big bluestem. The roots are not quite so deep but somewhat finer and more profusely branched. Elymus canadensis (nodding wild-rye) mostly occupies habitats similar to those of switchgrass. Its roots spread laterally $1 \frac{1}{2}-2$ feet; the network of branches is wonderfully well developed but extends downward scarcely more than 3 feet. On low moist or wet land about twenty-five other species of minor grasses and grasslike plants add to the living underground network already described.

MisCELlaneOus CHARACTERISTCS.-The approximate number of main roots in the upper 4 inches of soil has been ascertained by Pavlychenko (10): representative samples of Stipa spartea had 4400 roots per half square meter (5.38 square feet) of soil surface; those of Andropogon scoparius and of A.gerardi 

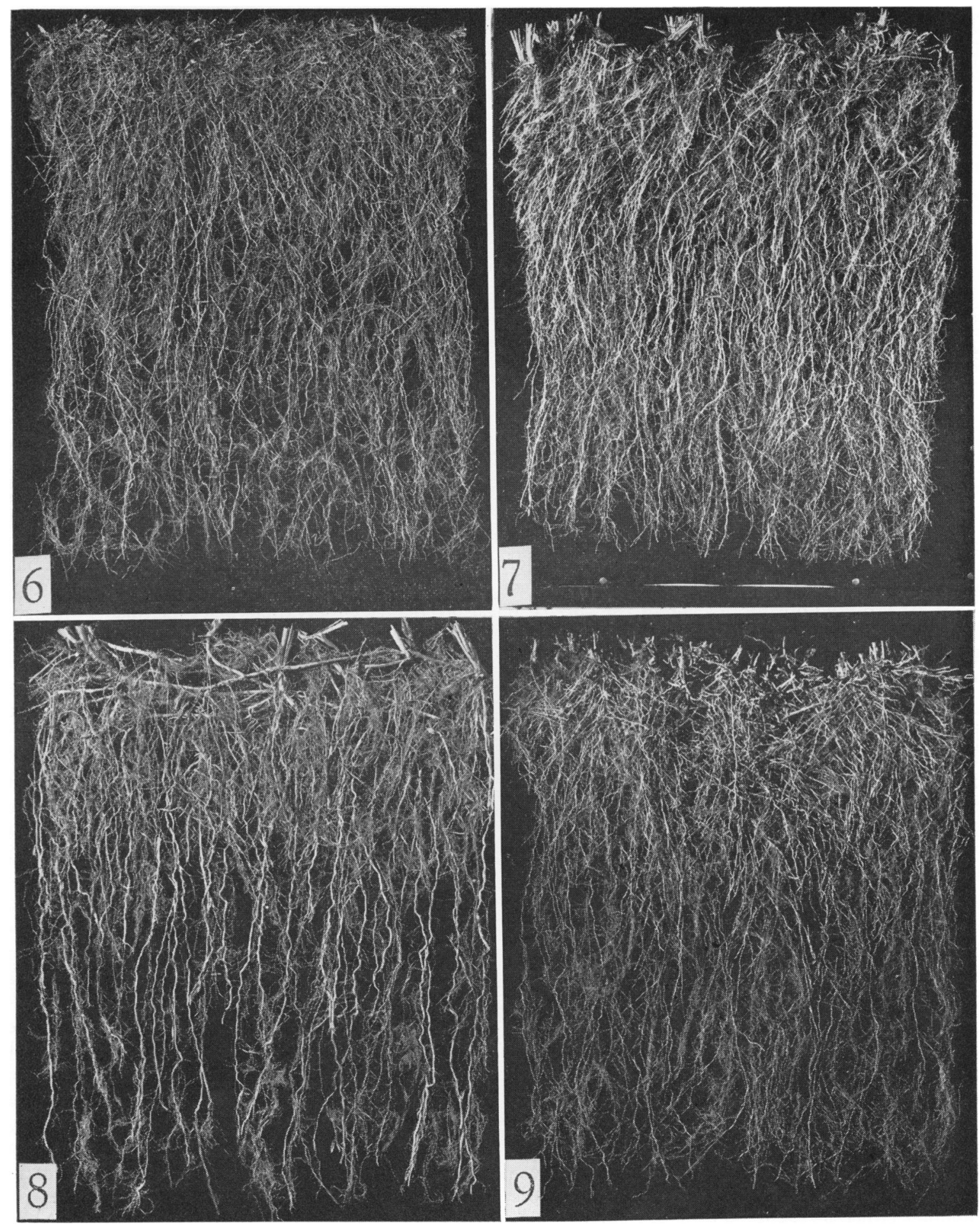

Figs. 6-9.- Root samples 2 feet wide, 3 inches thick, and $2 \frac{1}{2}$ feet deep. Fig. 6, root network of Andropogon gerardi (big bluestem) in its usual habitat in lowland soil where its roots penetrate deeply. Fig. 7, big bluestem from upland where root penetration was restricted by a claypan; roots are coarser, net-

work thicker, and weight in solum was greatly increased. Fig. 8, rhizomes and roots of Spartina pectinata (prairie cordgrass) forming open network except in surface soil. Fig. 9, root pattern of Panicum virgatum (switchgrass) which is intermediate in coarseness and density between two preceding grasses. 
(from upland) numbered about 3400 in a similar area. Thus, in figure 3 , a $3 \times 24$-inch surface of soil would contain approximately 400 roots.

Tensile strength of grass roots is very great. A main root of $S$. spartea will support a weight of 821 gm. before breaking and the main roots of the andropogons about $1712 \mathrm{gm}$. Even branches of the first order will support a weight of $31 \mathrm{gm}$. and those of the third order $2 \mathrm{gm}$. (10). Thus the root network as a whole is very strong.

The dry weight of the underground parts of the grasses has also been ascertained (16). Those in the surface foot of soil vary from 2.7 tons per acre for $S$. spartea to 4.4 tons for $A$. scoparius. The coarser rhizome-root network of $A$. gerard $i$ weighs 5.4 tons per acre and that of Spartina pectinata is about a third heavier.

The relation of root distribution to amount of organic matter has been determined (22). A typical square meter of vegetation was selected on the upland A. scoparius prairie on Sharpsburg loam, near Lincoln, and another on the lowland $A$. gerard $i$ prairie on Colo clay loam of the upper flood plain of the Missouri River. Roots and rhizomes constituted about $10 \%$ of the organic matter in the surface 6 inches of soil. In deeper sections the proportions decreased gradually to $3-4 \%$ in the second 6 inches, to $1 \%$ in the fourth foot of the Sharpsburg soil, and to $0.25 \%$ in the seventh foot of the Colo soil. Except for the surface 6 inches, there was an approximately linear relation between the amount of root material and the amount of soil organic matter in the various soil horizons. The dark, humified organic matter alone ranges from $30-40$ tons per acre in the top 6 inches of soil of our rich prairie land (13).

\section{FORBS}

The number of species of forbs in prairie is much greater than that of grasses: about 150 species occur in at least $10 \%$ of the prairies, and more than 200 others have been listed (21).

There is often much competition between forbs and grasses, both for a place in the sun and for water and nutrients. In a single square meter of prairie one can greatly increase the stature of forbs and/or the yield of individual grasses simply by removing half the plants. For a long time each spring certain forbs avoid this competition for light by producing elongated stems, often 10 inches or more in height, before unfolding either leaves or blossoms. Psoralea tenuiflora and Baptisia leucophaea are examples. Their coarse roots also extend 8 or more feet into the earth with very little branching in the solum. The bare stems of mature plants of $B$. leucantha are $3-3 \frac{1}{2}$ feet high before wide-spreading branches occur.

Various other forbs develop taproots of very large size, and little absorption by the main root or its branches occurs in the A horizon. Development above ground is often very extensive. An example is Silphium laciniatum, a tall coarse perennial varying in height from 4-10 feet. A single clump frequently has 100-150 large basal leaves. The shade is dense and the prairie grasses are absent, often over several square feet. Another example where competition in the upper soil is slight but is excessive above ground is the very long-lived Asclepias tuberosa. Still other forbs - and these are the most efficient competitorsboth occupy leaf-space from soil surface to leafy top, which is often at a greater height than the grasses, and their abundant fibrous roots are not unlike those of the grasses and extend as widely.

Since prairie is a closed community, it is very difficult for either seedling forbs or grasses to become established. The actual surface space occupied by the vegetation (the basal cover) is only about $11-15 \%$, but the shade is very great. Even when the seedling roots have extended deep into the network within the A horizon, lack of sufficient light may be fatal, or, during even temporary drought, the seedlings may fail to compete successfully for water with well-established plants. Observations and experiments throughout many years have shown that few seedlings occur in climax grassland. Most of the establishment probably occurs during the rare growing seasons of excessive moisture (2). Planting experiments have also shown that many long-lived forbs spend 2-3 years in the seedling stage before attaining a position of equal advantage with the grasses (3). Although sufficient establishment obviously occurs to maintain the prairie, long life of the individual and much vegetative reproduction by tillers, rhizomes, and root offshoots are characteristic of grasslands.

Once established forbs may live for many years. Individual plants of $A$. tuberosa and Kuhnia eupatorioides in our experimental prairies have been known to persist for at least 15 years. An old plant of Liatris punctata with fifty-four nearly erect stems and a lateral spread of 2 feet was examined in July, 1960. The stems arose from a very woody circular crown $8 \frac{1}{2}$ inches in diameter. When this was sawed in two, twenty-five annual rings showed plainly. Judging from the size of the decayed center, the plant may have attained an age of 40 years or more. The strong taproots of this species of blazing star frequently reach depths of 15 feet.

\section{BENEATH SOLUM}

ROOT NETWORK.- The upper soil layers, of course, are especially important since here have occurred most of the changes resulting from centuries of plant grow th. The importance of the parent materials, however, is demonstrated by the relatively great numbers 
of roots found there. Aside from grass roots, many legume roots with abundant nodules and roots of other prairie forbs occur. The ability of grasses and forbs to absorb water and nutrients at great depths has been demonstrated $(4,8)$.

Parent materials may be defined as the unconsolidated and more or less chemically weathered mineral materials from which soils may be synthesized, that is, a relatively inert storehouse of future soil material. In parent materials there are no granular crumbs, no prisms or horizontal plates, nor are there blocky layers which often make the separating out of roots so difficult; in fact, the parent materials are structureless (massive).

In the parent materials one finds earthworm burrows, sometimes to a depth of 13 feet; channels where deeply penetrating roots have lived, died, and decayed; and cracks or fissures often several feet deep and sometimes filled with the dark-colored soil washed down from above. Sand, gravel, glacial peb-
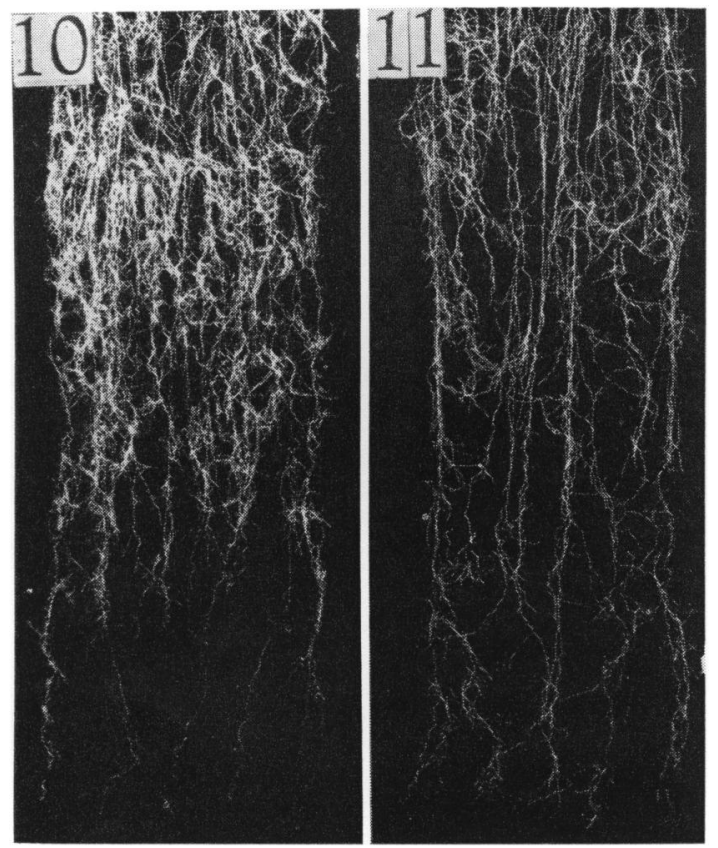

Figs. 10-11.-Roots from monoliths 12 inches wide and 3 inches thick, taken at depths of $2 \frac{1}{2}-5$ feet from Sharpsburg silty clay loam near Lincoln, Nebraska. Fig. 10, Andropogon scoparius. Fig. 11, A. gerardi.

bles, and pockets and seams of lime occur. In the deep unconsolidated deposits of soft, silty-textured, yellowish loess, the parent material is often nearly uniform throughout except for calcified capillary channels, concretions of lime, and sometimes shells of land snails. It is mellow, moist, and easily removed, even at 20-30 feet in depth, from the deeply penetrating roots of forbs. Plants take up calcium, potassium, phosphorus, and other nutrient elements from the parent materials and leave some part of these in the solum when they die.

The root network of grasses is well represented below $2 \frac{1}{2}$ feet, although more open in structure, and it extends well into the upper $\mathrm{C}$ horizon, sometimes to depths of several feet (figs. 10-15). On loess hills roots of Andropogon scoparius and Bouteloua curtipendula

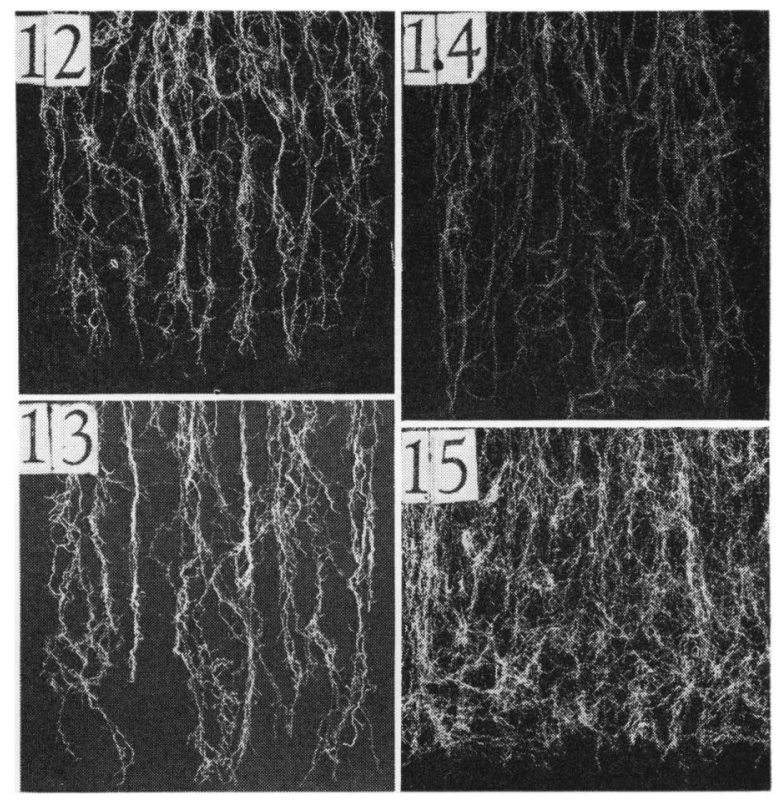

Figs. 12-15.-Roots of grasses in parent materials from monoliths 12 inches wide and 3 inches thick. Fig. 12, Andropogon scoparius, underlying Crete silty clay loam, Fig. 13, $A$. gerardi, underlying Crete silty clay loam. Fig. 14, Buchloe dactyloides, underlying a Chernozem silt loam. Fig. 15, Agropyron smithii, underlying a Rendzina soil near Belleville, Kansas.

often extend 5 feet into the parent materials, roots of A. gerardi $2 \frac{1}{2}-7$ feet, and roots of Agropyron smithii and Panicum virgatum even farther. There is usually a considerable reduction in number, as well as diameter, of the deeper roots but branching is always pronounced. Weight of the network is also greatly reduced, probably out of all proportion to the relative amount of absorption. An oven-dry weight of more than 300 pounds per acre of grass roots alone has been found in the fourth foot of unbroken bluestem prairie soil in eastern Nebraska (20). The deep roots sometimes sustain the life of a grass during extreme drought when the solum is very dry.

When one has worked with root systems for many years, he can visualize, when standing in a deep trench, what will be seen when the soil has been removed. Figure 16 is a sketch of such a mental image. For clarity the network of grass roots has been omitted and only an inch or two of the topsoil left in place. The figure shows the roots of forbs in an excavation 
28 feet wide, of similar length, and 20 feet deep. The root systems are of natural width and length and are representative of many prairie forbs. A dozen or more forbs in an area this size is common in prairie, although all of these particular species may not occur in such a group. When figure 16 is inverted, one gets a better idea of the considerable space between the forbs which, of course, is occupied by grasses. As long as the light above ground is not too subdued to permit forbs and grass to grow together, their roots are intimately intermixed. The abundant finer branches of forb roots, of course, could not be shown in the picture.

The root system of each species of plant has certain inherent characteristics such as length and depth of penetration and degree of proliferation, but soil conditions may modify them. The roots of most perennial forbs extend quite through the solum and far into the parent material. Thus, they have many partial habitats in the macro-environment. The plant does not grow in a uniform, homogeneous medium.

EFFECTS OF ROOTS ON PARENT MATERIALS.-A single deeply penetrating taproot forms upon its death and decay a pathway far into the parent materials. Often a single plant may produce several main roots which not only terminate far below the crown but spread outward a few inches to a few feet in the parent material. Each root may develop secondary, tertiary, and other branches which crisscross in their courses or terminate in small root masses. Moreover, several plants of a species often form open to dense societies. Thus, both individual and community networks are formed even by forbs with taproots. Such, for example, are those of the rose, psoralea, and lead plant, and scores of others. When the plant or societies produce fibrous roots widely spread along rhizomes, as do many goldenrods, asters, and numerous others, the networks are even more closely knit and bewilderingly complicated.

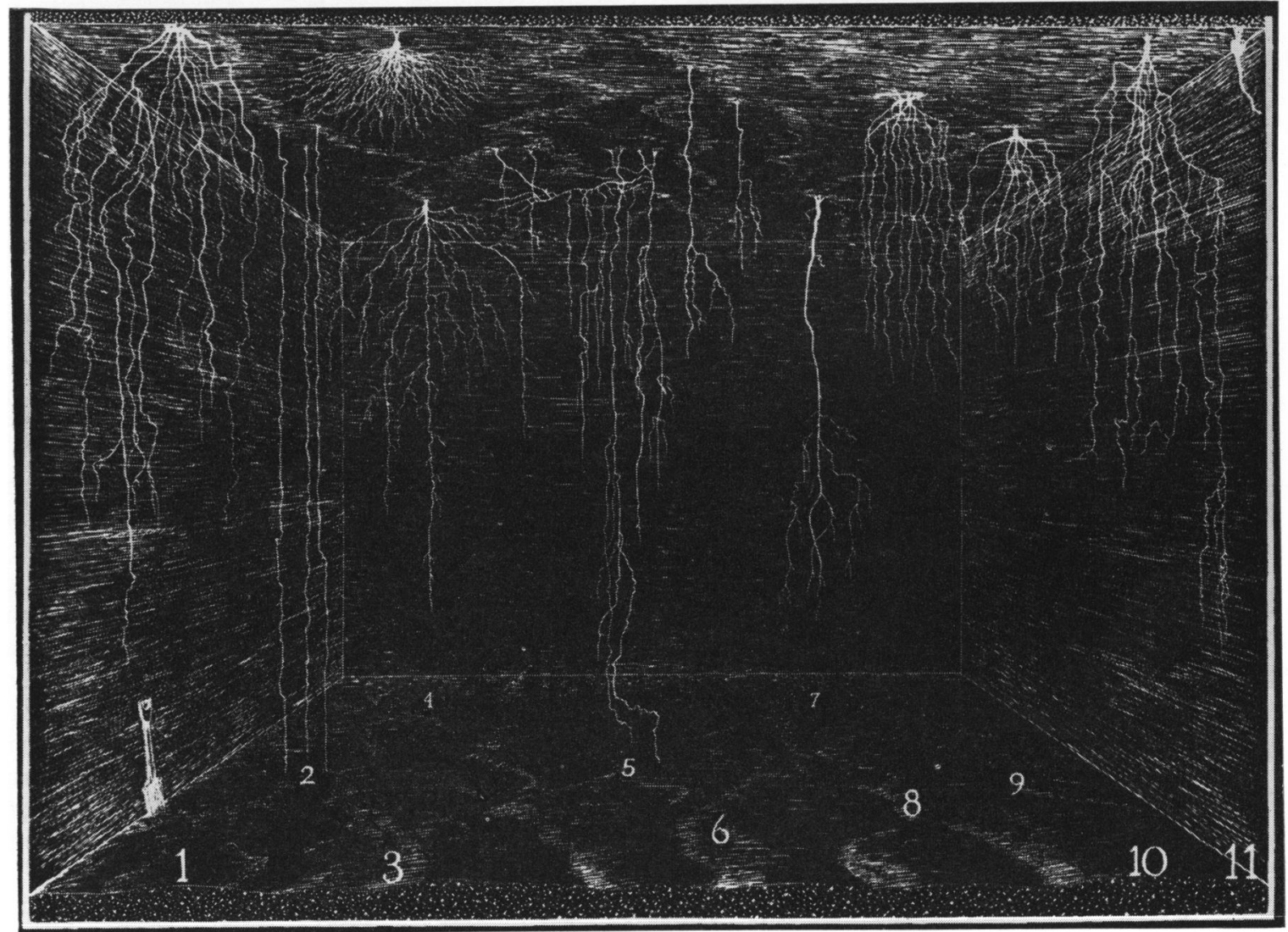

Fig. 16.-Excavation 20 feet deep showing root habits of several prairie forbs. 1, Amorpha canescens, lead plant; 2, Lygodesmia juncea, rush-like lygodesmia; 3, Liatris squarrosa, scaly blazing star; 4, Liatris punctata, dotted button snakeroot; 5 , Rosa suffulta, prairie rose; 6 , Echinacea pallida, pale purple coneflower; 7, Silphium laciniatum, compass plant; 8, Aster ericoides, many-flowered aster; 9, Astragalus crassicarpus, ground plum; 10, Glycyrrhiza lepidota, licorice; 11, Psoralea esculenta, prairie turnip, turning aside into wall. Redrawn from WEAVER $(14,15)$. 
Many changes in parent materials result from the presence of roots. The roots form small pores to large channels in the soil and thus increase the entry of water and air. Both have a profound effect upon chemical erosion. Conversely, roots take up water and nutrients and transport them upward, even above the soil. Leguminous plants, by the development of root nodules, often at all levels below the soil, produce available nitrogenous compounds continuously throughout their lives. Upon their death and decay, roots add a continuous, even if relatively small, amount of organic matter.

Old root channels are used again and again by new generations of roots. Grass roots often extend several inches beyond the general root depth whenever they enter an old root channel or an earthworm burrow. Roots of forbs follow former root paths downward or outward, often for several feet, before turning aside to make new ones.

Root channels furnish entry for a vast number of organisms that live in the soil. Many are animals that subsist mostly on living plant materials; others are largely predatory, or are parasitic, or subsist on plant residues. Algae, fungi, actinomycetes, and bacteria are representative plants. Each absorbing root is incased in an extremely well-populated but thin layer of soil - the rhizosphere-in which micro-organisms are especially abundant and active. Many or most of the various soil organisms probably also occur in the parent materials and add to the amount of organic matter, which is chiefly furnished by roots, and thus play a role in the preparation of soil from parent materials.

Usually forbs, about $14 \%$ of which are legumes, are scattered widely, but thinly, among the grasses. Societies, either pure or mixed, are rarely so numerous, except locally or in disturbed places, as to exceed the grasses in abundance. It seems improbable that deeply rooted prairie plants are sufficiently abundant to exhaust the soil moisture, except very locally, in the parent materials. This does happen, however, where deeply rooted crops of alfalfa (Medicago sativa) are grown. KIEsSELBACH et al. (9) found that alfalfa in a 2-year-old meadow near Lincoln, Nebraska, drew upon the moisture supply to a depth of 25 feet and in a 6-year-old meadow to a depth of 33 feet. The average moisture content between the fifth and fifteenth foot had been reduced $10.6 \%$ and $11 \%$, respectively, below that in adjoining cultivated fields. In the absence of alfalfa the subsoil below the sixth foot was free of cracks and crevices. Where alfalfa was growing, the shrinkage produced by removal of water had resulted in innumerable vertical fissures in the subsoil, some at 10-14 feet in depth were as much as 1 inch wide. In stabilized prairie, moisture in the parent material probably varies but little from year to year. Both number and size of forbs decrease in grassland with decrease in precipitation.

\section{Summary}

1. Interrelations of prairie soils and the living network of roots within them have been examined. Grassland soils contain and act upon a more extensive portion of prairie plants than does the atmosphere. In the large area of midcontinental grasslands in western Iowa, and eastern Nebraska and Kansas, the parent materials are wind-blown loess and glacial drift. Prairie vegetation, following or accompanying physical weathering, introduced the biological force which was largely responsible for constructional processes in the soil. The accumulation of organic matter, mostly from vegetation, in the A horizon was a major factor in soil formation in both Brunizem and Chernozem soils.

2. In Brunizems the $A$ horizon of dark-brown loam or silty clay loam is $8-16$ inches thick and the lighter colored clay loam or silty clay loam of the B horizon is 12-24 inches thick. Beneath these lies the pale-brown or light-yellow $\mathrm{C}$ horizon of parent materials from which these very productive soils have been formed. Roots of prairie plants penetrate entirely through the solum and deep into parent materials. The vegetation everywhere is associated with soils that are highly fertile because of the good supply of plant nutrient elements in the primary materials, an adequate amount of organic matter, and small amounts of leaching resulting from moderate (25-32 inches) precipitation.

3 . The root networks of the most abundant bunch grasses of uplands have been thoroughly examined. Andropogon scoparius is dominant over half of an area of 60,000 square miles, Stipa spartea and Sporobolus heterolepis form much smaller communities. Their root systems are similar in size, depth, and degree of branching. The many hundreds of roots per square foot, with their innumerable interwoven branches of great tensile strength, form a continuous network throughout the soil mile after mile. In the surface foot alone the dry weight of the root network is 2.7-4.4 tons per acre. The network becomes finer and more open with depth but it is normally 5 feet deep and thus extends downward well into the parent materials.

4. The equally wide-spread network formed by taller, sod-forming, lowland dominants-Andropogon gerardi, Spartina pectinata, and Panicum virgatum-is coarser, much heavier, and not so intricately branched. It continues much deeper, however, often to 8-10 feet, in these better watered soils.

5. The root system of each species of grass has 
certain inherent characteristics such as length, depth of penetration, and degree of proliferation, but these may be modified by soil conditions.

6. The root network of forbs supplements that of grasses and is especially conspicuous in the parent materials. On loess hills the roots of several grasses may extend 5-8 feet into the parent materials, but roots of many forbs have been shown to attain depths of $17-20$ or more feet.

7. Many changes in parent materials result from the presence of roots. Pores and channels are formed which accelerate the entry of water and air and thus increase chemical erosion. Roots absorb water and nutrients and transport them upward through the soil. Nodules with nitrogen-fixing bacteria occur at all depths on roots of legumes. Hordes of organisms that live in the soil find entry along old root channels and cause decay. They too finally die and add to the considerable, well-distributed organic matter from decayed roots. Thus, soil development and plant growth are intimately related even in the $\mathrm{C}$ horizon.

Department of Botany

UNIVERSITY OF NEBRASKA

LiNCOLN, NEBRASKA

\section{LITERATURE CITED}

1. Albertson, F. W. Ecology of mixed prairie in west central Kansas. Ecol. Monog. $7: 481-547.1937$.

2. Blake, A. K. Viability and germination of seeds and early life history of prairie plants. Ecol. Monog. 5:405-460. 1935.

3. Clements, F. E.; Weaver, J. E.; and Hanson, H. C. Plant competition. Carnegie Inst. Wash., Pub. 398. 1929.

4. Crist, J. W., and Weaver, J. E. Absorption of nutrients from subsoil in relation to crop yield. Bot. GAz. 77:121148. 1924.

5. Elder, J. A. In Soils of the North Central Region of the United States. North Central Regional Pub. no. 76 Conservation and Survey Div., University of Nebraska, Lincoln. 1960.

6. Fox, R. L.; Weaver, J. E.; and Lipps, R. C. Influence of certain soil-profile characteristics upon the distribution of roots of grasses. Agron. Jour. 45:583-589. 1953.

7. Hiтснсоск, A. S. Manual of the Grasses of the United States. Revised by Agnes Chase. U.S. Dept. Agr. Misc. Pub. no. 200. 1950.

8. Hunter, A. S., and Kelley, O. J. A new technique for studying the absorption of moisture and nutrients from soil by plants. Soil Sci. 62:441-450. 1946.

9. Kiesselbach, T. A.; Russel, J. C.; and Anderson, A. The significance of subsoil moisture in alfalfa production. Jour. Amer. Soc. Agron. 21:241-268. 1929.

10. Pavlychenko, T. K. Root systems of certain forage crops in relation to the management of agricultural soils. $\mathrm{Na}$ tional Res. Council, Canada, no. 1088. Ottawa. 1942.

11. Rice, C. M. Dictionary of Geological Terms. Edwards Brothers, Ann Arbor, Mich. 1955.

12. Riecken, F. F. In Soils of the North Central Regicn of the
United States. North Central Regional Pub. no. 76. Conservation and Survey Div., University of Nebraska, Lincoln. 1960.

13. THORP, J. How soils develop under grass. Pp. 55-66 in U.S. Dept. Agr. Yearbook. Government Printing Office, Washington, D.C. 1948.

14. Weaver, J. E. Ecological relations of roots. Carnegie Inst. Wash. Pub. 286. 1919.

15. - Rcot development in the grassland formation. Carnegie Inst. Wash. Pub. 292. 1920.

16. - Summary and interpretation of underground development in natural grassland communities. Ecol. Monog. 28:55-78. 1958.

17. —. Flood plain vegetation of the Central Missouri Valley and contacts of woodland with prairie. Ecol. Monog. 30:37-64. 1960

18. Weaver, J. E., and Albertson, F. W. Resurvey of grasses, forbs, and underground plant parts at the end of the great drought. Ecol. Monog. 13:63-117. 1943.

19. Weaver, J. E., and Darland, R. W. Quantitative study of root systems in different soil types. Science 110:164-165. 1949.

20. — tive grasses in various soil types. Ecol. Monog. 19:303-338. 1949.

21. Weaver, J. E., and Fitzpatrick, T. J. The prairie. Ecol. Monog. 4:109-295. 1934.

22. Weaver, J. E.; Hougen, V. H.; and Weldon, M. D. Relation of root distribution to organic matter in prairie scil. Bот. GAZ. 96:389-420. 1935.

23. Weaver, J. E., and Voigt, J. W. Monolith method of rootsampling in studies on succession and degeneration. BoT. GAz. $111: 286-299.1950$. 